\title{
Selected Metal (Fe, Cu and Zn) Levels in Fish and Water at Abaya and Chamo Rift Valley Lakes
}

\author{
Dugasa Gerenfes ${ }^{1, *}$, Endale Teju ${ }^{2, *}$, Tesfahun Kebede ${ }^{2}$ \\ ${ }^{1}$ Department of Agricultural and Nutrition Research Program, Ethiopian Institute of Agriculture Research (EIAR), Kulumsa Agricultural \\ Research Center, Assela, Ethiopia \\ ${ }^{2}$ Departments of Chemistry, College of Natural and Computation Science, Haramaya University, Haramaya, Ethiopia
}

Email address:

dgerenfes2017@gmail.com (D. Gerenfes), endaleteju $a$ yahoo.com (E. Teju)

${ }^{*}$ Corresponding author

\section{To cite this article:}

Dugasa Gerenfes, Endale Teju, Tesfahun Kebede. Selected Metal (Fe, Cu and Zn) Levels in Fish and Water at Abaya and Chamo Rift Valley Lakes. Biochemistry and Molecular Biology. Vol. 4, No. 2, 2019, pp. 17-27. doi: 10.11648/j.bmb.20190402.11

Received: January 18, 2019; Accepted: May 9, 2019; Published: June 24, 2019

\begin{abstract}
Samples of fish organs and water were collected from three sampling sites of Lakes Chamo and Abaya. A procedure consuming $12 \mathrm{~mL}$ mixture of $\mathrm{HNO}_{3}-\mathrm{H}_{2} \mathrm{O}_{2}$ for gill, kidney, liver and 1:2.5 mL mixture of $\mathrm{HNO}_{3}-\mathrm{HCl}$ for water samples for digestion of was developed. Concentrations of three metals in water and their accumulation in Tilapia (Oreochromis niloticus) and Barbus (Labeobarbus intermedius) fish species were determined using Flame Atomic Absorption Spectroscopy. Concentrations of metals in gills, kidney, liver and water varied $(\mathrm{mg} / \mathrm{kg}): \mathrm{Zn} 0.061-0.083,0.047-0.076,0.070-$ 0.074, 0.011-0.024, respectively; $\mathrm{Cu} ; 0.025-0.031,0.028-0.043,0.029-0.044,0.023-0.092$, respectively; $\mathrm{Fe} 2.934-3.583,2.735$ $3.628,0.809-2.723,4.756-10.240$, respectively. Most of the elements in water samples occurred below detection limit. The highest accumulations of iron $(\mathrm{Fe})$ concentration were observed in liver and gill of Tilapia fish from Chamo Lake. Among the detected metals, zinc $(\mathrm{Zn})$ showed the maximum bioaccumulation factor in both fish species from both lakes, while iron was the least bio accumulated metallic species. Using Pearson correlation, positive correlation was observed for the specific fish organ with water samples. There was no significant difference between the two lakes in accumulating trace metals however lake chamo had higher concentration.
\end{abstract}

Keywords: Bioaccumulation, Fish, Metals, Labeobarbus Intermedius, Lake Abaya, Lake Chamo, Oreochromis Niloticus

\section{Introduction}

\subsection{Literature Review}

With changing environmental conditions and increasing anthropogenic influences, the nature of water bodies that serve as a habitat for aquatic life will change. Studies on the level of trace elements in organisms inhabiting in lakes and other water bodies provide information on the status of the aquatic environment and the biota residing in them. Many studies of metals in fish of fresh waters, wetlands and seas indicate an accumulation of trace elements and raise serious environmental concern [1]. Despite the growing influences from natural and anthropogenic origins, there exists a general belief that presumes absence of permanent alteration or contamination of these Lakes. However, rivers that flow into some of these Lakes are heavily loaded with contaminants of natural and anthropogenic origin such as discharges from factories and domestic sources [1, 2].

Metals have wide environmental dispersion with the tendency to accumulate in selective tissues of the living organisms and have overall potential to be toxic even at relatively low levels of exposure. In the fish body, the metal is transported through the blood stream and either stored, transformed or eliminated in the liver, kidney or the gills [3]. At high concentrations, they are dangerous because they accumulate faster in living things such as fish than they are broken down.

However, fishes are good indicators of metal contamination in aquatic systems because they occupy different trophic levels and are of different sizes and ages [4]. 
The consumption of contaminated fish causes acute and chronic effects to humans [5]. This situation has arisen as a result of the rapid growth of population, increased urbanization and expansion of industrial activities, exploration and exploitation of natural resources, extension of irrigation and other modern agricultural practices as well as the lack of environmental regulations [6].

The aim of this study is to detect the concentrations of selected metals viz. $\mathrm{Fe}, \mathrm{Cu}$ and $\mathrm{Zn}$ in water and fish species (Oreochromisniloticus and Labeobarbusintermedius from Chamo and Abaya lakes. The study was necessary as a large number of people consume the fish species in this area, but there is no literature report on selected metal concentrations in water, Tilapia and Barbus fish species in which can be used to show the extent of the problems in the two Rift Valley lakes.

\subsection{Objectives}

\subsubsection{General Objective of This Study Was}

To study Selected metal (Fe, $\mathrm{Cu}$ and $\mathrm{Zn}$ ) levels in fish and water at Abaya and Chamo Rift Valley lakes by flame atomic absorption spectrometry (FAAS).

\subsubsection{The Specific Objectives of the Study Were}

1. To determine the levels of selected metals $\mathrm{Zn}, \mathrm{Cu}$ and $\mathrm{Fe}$ in the water and fish samples from Abaya and Chamo Lakes.

2. To determine the bioaccumulation factors of the selected metals in fish samples.

3. To investigate the correlation levels of metals between the samples of lake water and fish species.

\section{Materials and Methods}

\subsection{Description of the Study Area}

The Abaya Chamo drainage basin is a sub basin of the Rift Valley Lakes that passes through midway in the North South direction of Nations, Nationalities and Peoples Region of Southern Ethiopia. A number of small brooks and ephemeral rivers inter into the Abaya Lake. The altitude of the region varies between 4200 meter (Mount Guge) and 1108 meter above sea level (at the outflow from the Chamo Lake). The lakes are located about $510 \mathrm{Km}$ South of Addis Ababa between $5^{\circ} 3$ ' $19^{\prime \prime}$ and $6^{0} 45^{\prime} 11^{\prime}$ " North latitude and $37^{\circ}$ 18 '55" and $38^{\circ} 7$ ' $55^{\prime \prime}$ East longitude. These lakes are located within the Main Ethiopian Rift Valley (MER), which extends from the Southern Afar to the Konso highland in the southern Ethiopia.

Lake Abaya is 60 kilometers long and 20 kilometers wide, with a surface area of $1162 \mathrm{Km}^{2}$. It has a maximum depth of $13.1 \mathrm{~m}$ and is at an elevation of $1285 \mathrm{~m}$. Lake Chamo is one of the three large lakes in Ethiopia next to Lake Tana and Abaya. It is located in the Great Rift Valley Lake at an elevation of 1, 235 meters. It is just to the south of Lake Abaya and the city of Arba Minch, and East of the Guge Mountains. Lake Chamo is $26 \mathrm{Km}$ long and $22 \mathrm{Km}$ wide, with a surface area of $551 \mathrm{Km}^{2}$ and a maximum depth of 10 $\mathrm{m}$. The lake climate is further characterized by high rate of evaporation (about $2300 \mathrm{~mm}$ per year on average) and the precipitation average of about $600 \mathrm{~mm}$. The area in the past has been affected by global climatic change with a shift to a decrease in precipitation peaks and with consequent impact on the lakes. Therefore, its salinity increases progressively which affects greatly the lake biota [7].

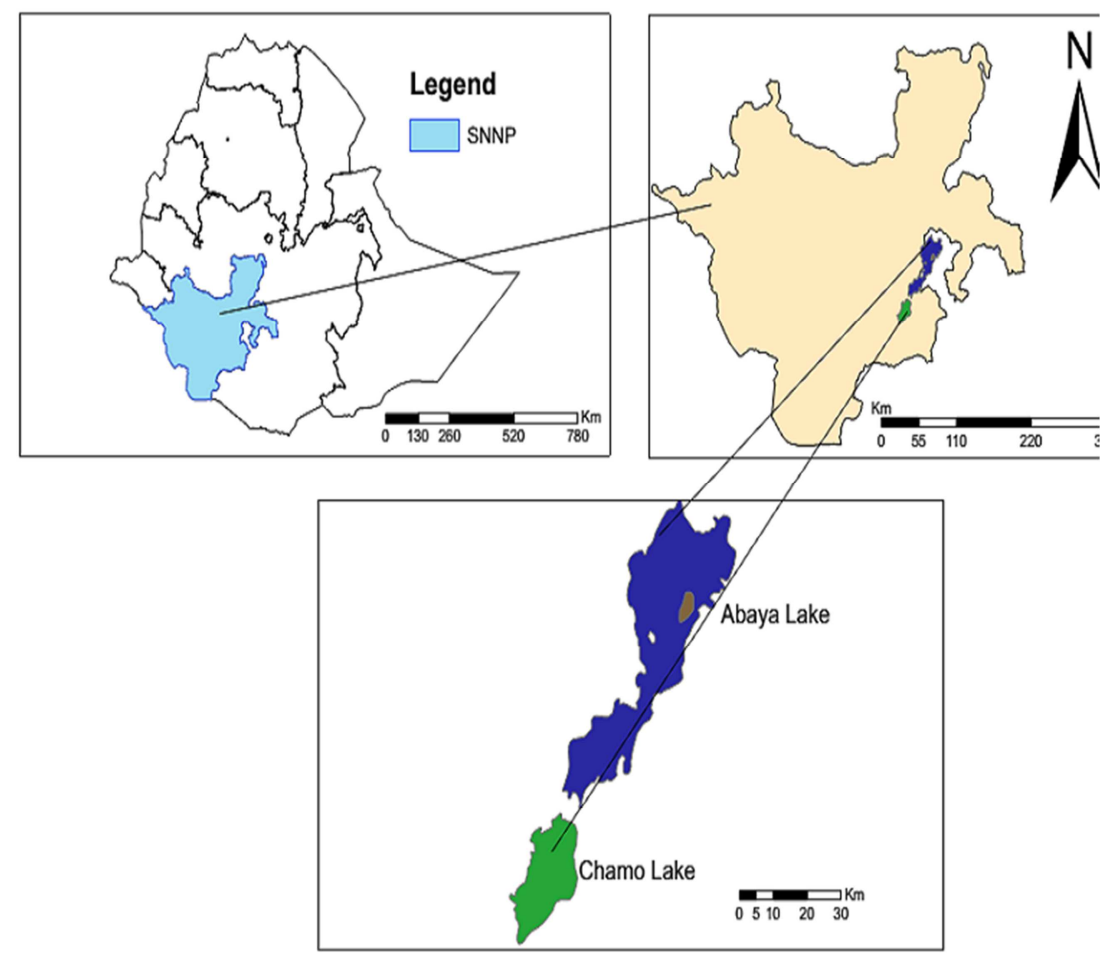

Figure 1. Map showing the location of Lakes Chamo and Abaya. 


\subsection{Instruments and Chemicals}

\subsubsection{Instruments and Apparatus}

The instrument used was fully automated PC-controlled double-beam atomic absorption spectrometer with FS (fast sequential operation) for fast multi element air acetylene flame AA determinations. Its features have 4 lamp positions and automatic lamp selection, operated with specter AA Base and pro-software versions with each six hollow cathode lamps namely Cadmium, Zinc, Chromium, Cupper, Iron and lead were used throughout the experiment. A Microprossecer based PH-electirical conductivity-meter; Model 1615 was used for the determination of water $\mathrm{pH}$ and conductivity. The common laboratory apparatus which were used during the study include different sized beakers, Erlenmeyer flasks, funnels, graduated cylinders, volumetric flasks, block digester, fume hood, shaker, droppers, glass pipettes, icebox, spatula, measuring cylinders, plastic knife, plastic net, vinyl gloves, stirrer, polyethylene bags, analytical balance, crucibles, oven, mortar and pestle.

\subsubsection{Reagents and Chemicals}

All the reagents and chemicals used in the present study were analytical grade. Deionized water was used for all preparation and dilution purposes throughout the study. Nitric acid, $\mathrm{HNO}_{3}$ (Spectrosol®, England) (69\%), Potassium chloride, $\mathrm{KCl}(0.01 \mathrm{~N})$, Hydrogen peroxide, $\mathrm{H}_{2} \mathrm{O}_{2} \quad(30 \%) \quad$ (Spectrosol $\AA$, BDH, England) and hydrochloric acid $\mathrm{HCl},(36 \%)$ were used for fish sample digestion. Working standards of $1000 \mathrm{ppm}$ were prepared for selected heavy metals ( $\mathrm{Zn}, \mathrm{Cu}$ and $\mathrm{Fe}$ ) (Puro Graphictm calibration standards, Buck Scientific, USA). Buffer solutions of $\mathrm{pH} 4$ and 7 were used for $\mathrm{pH}$ meter calibration and potassium chloride was used for conductivity meter calibration [8].

\subsection{Sample Collection}

\subsubsection{Fish Sampling and Drying}

The selected fish species were randomly collected with the help of local fishermen within the sampling stations by using plastic nets. The freshly collected fish varieties were two types namely Tilapia (Oreochromis neloticus) and Barbus (Labeobarbus intermedius). First the scales of the fish were removed with plastic knife and the selected body parts (gills, kidney and liver) were removed carefully and separately. At the sites, gill, kidney and liver samples were removed from different fishes of the same species and washed with the Lake water, distilled water; $\mathrm{HNO}_{3}$ containing distilled water and was combined to form a single composite sample and placed in labeled plastic bags. Immediately, the plastic bags were closed with masking tape, frozen in icebox and transported to the laboratory for drying and further treatment [9].

\subsubsection{Collections of Water Samples}

Water samples were collected from six stations of each of the two lakes (Sile1, Sile2, Chamo Park1, Chamo Park2, Kulfo1 and Kulfo2 from Lake Chamo, Bilate1, Bilate2,
Lante1 Lante2, Alge1 and Alge2) in March from Chamo and Abaya lakes. This was performed at the internal of $50 \mathrm{~cm}$ with $50 \mathrm{~m}$ distance from first point to internal part by using boat in order to get representative sample and $50 \mathrm{~cm}$ depth was considered in order to exclude the dust materials as well as oily liquids suspended above the Lake and collected in to the container [9]. A water sampler polyethylene bottle with $1 \mathrm{~L}$ capacity was used to collect surface water from the three different sites. All sampling bottles were cleaned before use with detergents and rinsed with deionized water for the sampling purpose. During the sampling period the bottles were rinsed with the lake water three times and then used for collecting the samples. Finally, the freshly collected water samples were mixed together and taken as composite samples for digestion process from each lake. The collected samples were placed in icebox and transported to the laboratory for further treatment.

\subsection{Digestion Procedures of Fish and Water Samples}

\subsubsection{Digestion Procedure of Fish Samples}

Fish gills, kidney and liver parts were dried in an electric oven at $100-105^{\circ} \mathrm{C}$ until constant weight was obtained. The samples were crushed using a clean mortar and pestle to produce powdered forms. A homogenized $0.5 \mathrm{~g}$ of each grounded fish, powder sample was weighed using analytical balance. Each of $0.5 \mathrm{~g}$ of powder sample was then transferred into a digestion flask into volume $12 \mathrm{~mL}$ of a mixture of Nitric acid (70\%, Spectrosol) and hydrogen peroxide (35\%, Riedel-de Haen) prepared in a 1:1 (v/v) ratio was added. The suspended mixture was digested for one hour, until a clear solution was obtained [8]. After that, it was allowed to cool and then filtered through Whatman filter paper No.42. Finally, the filtrate so obtained was diluted to $50 \mathrm{~mL}$ in a volumetric flask with deionized water and get a side for later analysis of the heavy metals content using Flame Atomic Absorption Spectrophotometer.

\subsubsection{Digestion of Water Samples}

Digestion of water took place after composite samples were prepared from the two Lakes. First of all, mark in about $20 \mathrm{~mL}$ of the beaker was made using marker. According to the Methods developed by the United State Environmental Protection Agency (USEPA) 3005 a $50 \mathrm{~mL}$ aliquot of well mixed water samples were digested in a beaker covered with a watch glass by adding $1 \mathrm{~mL}$ of concentrated (69-72\%) $\mathrm{HNO}_{3}$ and $2.5 \mathrm{~mL}$ of concentrated $(30 \%) \mathrm{HCl}$ and heated on a hot plate at $90^{\circ} \mathrm{C}$ boiled until the solution reached up to the mark $(20 \mathrm{~mL})$. Then the beaker was removed and cooled. Each of the digested water samples was filtered through Whatman filter paper No.42 in to a $100 \mathrm{~mL}$ volumetric flask and filled up to the mark with deionized water by addition of $2 \mathrm{~mL}$ of nitric acid to get a clear solution [9].

\subsection{Method Validation for Metal Analysis}

\subsubsection{Preparation of Stock Standard Solution}

Working standard solutions of iron $(\mathrm{Fe})$, copper $(\mathrm{Cu})$ 
and zinc $(\mathrm{Zn})$ were prepared from the stock standard solutions containing $1000 \mathrm{ppm}$ of element in $2 \mathrm{~N}$ nitric acid. Calibration and measurement of elements were done by using Atomic Absorption Spectrophotometer. The calibration curves were prepared for each element individually applying linear correlation by least square method. A blank reading was also taken and necessary corrections were made during the calculation of concentration of various elements.

\subsubsection{Instrumental Calibration}

Calibration curves were prepared to determine the concentration of metals in the sample solutions. Intermediate standard solution $(100 \mathrm{mg} / \mathrm{L})$ of each metal was prepared from stock standard solutions containing $1000 \mathrm{mg} / \mathrm{L}$ of $\mathrm{Cu}, \mathrm{Zn}$ and $\mathrm{Fe}$. Appropriate working standards were prepared for each metal solution using serial dilution of the intermediate solution using extraction solution. According to the instrument operation manual to attain its better sensitivity, the working standards were then aspirated one after the other into the flame atomic absorption spectrometer and its absorbance was recorded. Calibration curves were plotted with different points for each metal standard solution using absorbance against concentrations $(\mathrm{mg} / \mathrm{L})$. Immediately after calibration using the standard solutions, the sample solutions were aspirated in to the instrument and direct reading of the metal concentrations were recorded.

\subsection{Analytical Method Validation}

\subsubsection{Method Detection Limit}

Three replicate blank samples were digested following the same procedures utilized for digesting the fish and water samples. Each blank was assayed for its metal contents (Zn, $\mathrm{Fe}$ and $\mathrm{Cu}$ ) by FAAS. The SD of the three replicate blanks was calculated to determine the MDL [10]. Method detection limit (MDL) was then calculated according to equation indicated below $[10,11]$.

$$
\mathrm{MDL}=\mathrm{yB}+3 \mathrm{SD}
$$

Where; $y B=$ mean of the replicate blank.

$\mathrm{SD}=$ Standard deviation of the blank.

\subsubsection{Recovery Test}

Recovery is one of the most commonly used techniques utilized for validation of the analytical results and evaluating how far the method is acceptable for its intended purpose. In present study due to the absence of certified reference material for fish and water in our laboratory, the validity of the digestion procedure, precision and accuracy of FAAS was assured by spiking fish and water samples with standard of known concentration. The spiked and non-spiked fish and water samples were digested following the same procedure employed in the digestion of the respective samples and analyzed in similar condition. Then the percentage recoveries of the analytes were calculated [9].

$$
\text { Recovery }=\frac{\mathrm{CM} \text { in the spike sample }-\mathrm{CM} \text { in the non spike sample }}{\text { Amount added }} \times 100 \%
$$

Where, $\mathrm{CM}=$ concentration of metal interest

The acceptable ranges of percentage recovery for metals analysis were within 80-120\% [12].

\subsection{Bioaccumulation Factor (BAF)}

The bioaccumulation factor (BAF) is the ratio between the accumulated concentration of a given pollutant in any organ and their dissolved concentrations in water [13]. The bioaccumulation factor (BAF) for the actual metal accumulation in fish tissues from that of lake water was estimated as:

\section{Results and Discussion}

\subsection{Physicochemical Variables of Water Samples}

\begin{tabular}{|c|c|c|c|c|c|}
\hline \multicolumn{6}{|c|}{ Physicochemical Parameters } \\
\hline \multicolumn{6}{|c|}{ Lake Chamo Lake Abaya } \\
\hline Sites & $\mathbf{p H}$ & $\mathrm{EC}(\boldsymbol{\mu S} / \mathbf{c m})$ & Sites & $\mathbf{p H}$ & $\mathrm{EC}(\boldsymbol{\mu S} / \mathbf{c m})$ \\
\hline Sile1 & $7.66 \pm 0.15$ & $843.67 \pm 7.02$ & Bilate1 & $7.29 \pm 0.65$ & $520.67 \pm 8.02$ \\
\hline Sile2 & $8.23 \pm 0.29$ & $818 \pm 4.53$ & Bilate2 & $7.29 \pm 0.70$ & $485.33 \pm 10.41$ \\
\hline Chamo park1 & $8.33 \pm 0.19$ & $781 \pm 14$ & Lante1 & $8.09 \pm 0.48$ & $488.67 \pm 6.03$ \\
\hline Chamo park2 & $8.35 \pm 0.17$ & $795 \pm 10.02$ & Lante2 & $7.99 \pm 0.15$ & $477.00 \pm 7.00$ \\
\hline Kulfo1 & $8.52 \pm 0.18$ & $836.33 \pm 12.86$ & Alge1 & $7.91 \pm 0.25$ & $525.67 \pm 9.61$ \\
\hline
\end{tabular}

Table 1. The mean $\pm S D$ values of some physicochemical properties of Chamo and Abaya Lakes at the three sampling sites.

$$
\mathrm{BAF}=\frac{\text { Concentration of metals in fish tissue }\left(\frac{\mathrm{mg}}{\mathrm{L}}\right)}{\text { Concetration of metals in sea water }\left(\frac{\mathrm{mg}}{\mathrm{L}}\right)}
$$

\subsection{Statistical Analysis}

The analysis of variance ANOVA was used to examine the significance level of all parameters measured. Least Significant Difference (LSD) test was used for means comparison. The level of significance for the t-test and means comparison was at $\mathrm{p}<0.05$. The concentrations of all metals in fish and water sample were expressed in $\mathrm{mg} / \mathrm{L}$. 
The $\mathrm{pH}$ of Lake Chamo ranged from 7.66 $\pm 0.15-8.52 \pm 0.18$ at the site of Sile and kulfo inlets, respectively, whereas the $\mathrm{pH}$ of Lake Abaya ranged from $7.29 \pm 0.65-8.09 \pm 0.48$ at the site of Bilate and Lante inlets, respectively. The values of $\mathrm{pH}$ has relatively decreased in the lake when compared with the values lake Hawassa $(\mathrm{pH}=8.5)$ and $(\mathrm{pH}=8.8)$ reported from previous researches done $[14,15]$. These may reveal that there is a notable increment in the organic matter load of the lake system. The $\mathrm{pH}$ of the lake is within permissible limits for drinking, recreation, agricultural and aquatic life water use $(6.5-9)[16,17]$. The $\mathrm{pH}$ values investigated in the present study are relatively low when compared with other lakes, which may be recognized to the decomposition of organic matter in the course of time.

Conductivity is a measure of the ability of aqueous solution to carry an electric current that depends on the presence and total concentrations of ions, their mobility, valance and on the temperature. The mean levels of electrical conductivity of both lakes were recorded by conductometry using an instrument of model 4310. In all sampling sites the EC values of Lake Chamo ranged from $773.67 \pm 6.03$ to $843.67 \pm 7.02 \mu \mathrm{S} / \mathrm{cm}$ at the inlet of Kulfo and Sile sites, respectively; whereas the EC values of the Lake Abaya were ranged from $477 \pm 7.00$ to $525.67 \pm 9.61 \mu \mathrm{S} / \mathrm{cm}$ at Lante and Alge, sites respectively. All these values are by far below the guideline value recommended for drinking purpose $(1500$ $\mu \mathrm{S} / \mathrm{cm})$ as well as the EPA guideline value of $(1000 \mu \mathrm{S} / \mathrm{cm})$ [17]. Therefore, the EC values for both lakes can be assessed under excellent classes for all livestock, poultry and irrigating purposes $<1000 \mu \mathrm{S} / \mathrm{cm}$ ) [18]. The observed variations of these values however may be accounted for the changes in the water level as a result of high rate of evaporation and lowering of the amount of drainage water pouring into the lake. The lower values are due to direct effect of dilution by drainage water especially in areas facing the drains.

\subsection{Method of Detection Limit}

Method of detection limit is defined as the minimum concentration of analyte that can bemeasured. In other words, it is the lowest analyte concentration that can be distinguished from statistical variations in a blank, which usually correspond to the signal of blank three times the standard deviation of the blank ( $3 \delta$ blank, where $\delta=$ standard deviation of the blanks) [10]. As shown in table 2, the method detection limits of the investigated elements by FAAS along with their instrument detection limits are presented, respectively.

Table 2. Instrument and method detection limit.

\begin{tabular}{llll}
\hline Elements & IDL $\mathbf{~ m g / L}$ & MDL of Water sample $(\mathbf{m g} / \mathbf{L})$ & MDL of Fish sample (mg/L) \\
\hline $\mathrm{Zn}$ & 0.001 & 0.003 & 0.004 \\
$\mathrm{Cu}$ & 0.003 & 0.006 & 0.007 \\
$\mathrm{Fe}$ & 0.005 & 0.010 & 0.012 \\
\hline
\end{tabular}

\subsection{Calibration Curves}

Calibration curves for $\mathrm{Zn}, \mathrm{Fe}$ and $\mathrm{Cu}$ were obtained by using suitable standard solutions prepared from stock solutions. Calibration standards for the elements analyzed were prepared in concentration ranges expected for the analytes in the samples analyzed. In addition, the calibration standards were prepared by taking into consideration the optimum working ranges of the elements. The determination coefficient $\left(\mathrm{R}^{2}\right)$ values that are closer to the absolute value of 1 indicate that there is a strong relationship between the variables being determined whereas values closer to zero $(0)$ indicate that there is no linear relationship between absorbance and concentration [3]. The determination coefficients of the elements were determined using prepared standards concentration versus their corresponding absorbance.

\subsection{Recovery of the Experimental Procedure}

The procedures used in the current study were validated by spiking experiments for recovery determination which is usually helpful in the absence of certified reference material to evaluate the accuracy of the method applied for the analyte determination. This was performed by carefully spiking the standard solution prepared, in to water and fish samples to evaluate the extent to which the standard added could be recovered after determination through sample preparation. The percent recovery was calculated after small and known amounts of the heavy metals from the stock solutions were added or spiked in to the water and fish samples to be digested and after absorbance of both spiked and non-spiked samples were read. Results were obtained through calculation. Method validation is the process of providing that analytical method is acceptable for its intended purpose. For water sample, the percentage recovery lie in the range of $85.00-95.35 \%$ for Lake Chamo, 83.00 - $92.7 \%$ for Abaya Lake, which are within the acceptable range for each metal. Similarly, the recoveries of fish samples obtained from Lake Chamo varied from 87.00-98.50 and 87.00 - 95.50\% in Tilapia and Barbus fish respectively. Although, the recoveries obtained from Lake Abaya varied from 87.00-95.50\% and 88.5-93.5 \% in Tilapia and Barbus fish respectively. These values were within the acceptable range of 80 to $120 \%$ for the elements indicating good accuracy for the analysis procedure [19].

\subsection{Evaluation of Analytical Data}

Errors in analytical results are most often expressed using 
accuracy and precision. The precision of an analytical procedure expresses the closeness or agreement between a series of measurements obtained from multiple sampling of the same homogeneous sample under the established conditions whereas the accuracy of an analytical procedure expresses the closeness of measurements to the true value. The precision of an analytical procedure is usually expressed as the variance, standard deviation or coefficient of variation of a series of measurements [20]. In the current study the precision of the results were evaluated by the standard deviation and relative standard deviation of the results of three replicate measurements $(n=3)$. These parameters are useful in estimating indeterminate error. The results of the present analysis are reported with the corresponding standard deviation and relative standard deviation. As shown in Tables 3 , the percent relative standard deviation determined was less than 10 for all samples which indicate acceptable variability of the analytical results.

\subsection{Levels of Selected Metals in Water Sample}

The dissolved metal concentrations in Chamo and Abaya Lake water were measured at the six sampling sites (Sile, Chamo Park, Kulfo, Bilate, Lante and Alge) during the dry season. The concentrations of dissolved heavy metals in Chamo and Abaya lakes were found to be above the instrumental detection limit (FAAS) in all sampling sites. The average concentration $(\mathrm{mg} / \mathrm{L})$ of heavy metals in water sample from both study sites are shown in Table 3. Statistical analysis shows that the metal concentrations in the water samples differed significantly $(\mathrm{p}<0.05)$. However, there was no significance difference in each elements in water samples collected in different sampling occasions $(\mathrm{p}<0.05)$.

Table 3. The mean $\pm S D(\mathrm{mg} / \mathrm{L})$ of heavy metal concentrations in water samples from Abaya and Chamo Lakes at three sampling sites $(n=3)$.

\begin{tabular}{|c|c|c|c|}
\hline Site & $\mathbf{Z n}$ & $\mathbf{C u}$ & $\mathbf{F e}$ \\
\hline \multicolumn{4}{|c|}{ Selected Metals in water sample from Lake Abaya } \\
\hline B1 & $0.020 \pm 0.002^{\mathrm{b}}$ & $0.030 \pm 0.002^{\mathrm{ab}}$ & $6.474 \pm 0.185^{\mathrm{b}}$ \\
\hline B2 & $0.024 \pm 0.001^{\mathrm{a}}$ & $0.025 \pm 0.002^{\mathrm{c}}$ & $5.939 \pm 0.039 \mathrm{c}$ \\
\hline L1 & $0.023 \pm 0.001^{\mathrm{a}}$ & $0.029 \pm 0.002^{\mathrm{ab}}$ & $7.094 \pm 0.355^{\mathrm{a}}$ \\
\hline $\mathrm{L} 2$ & $0.016 \pm 0.001^{\mathrm{d}}$ & $0.029 \pm 0.003^{\mathrm{ab}}$ & $5.012 \pm 0.130^{\mathrm{de}}$ \\
\hline A1 & $0.012 \pm 0.001^{\mathrm{c}}$ & $0.023 \pm 0.002^{\mathrm{c}}$ & $4.756 \pm 0.350^{\mathrm{e}}$ \\
\hline $\mathrm{A} 2$ & $0.011 \pm 0.001^{\mathrm{c}}$ & $0.033 \pm 0.003^{\mathrm{a}}$ & $5.486 \pm 0.307^{\mathrm{cd}}$ \\
\hline \multicolumn{4}{|c|}{ Selected metals in water sample from Lake Chamo } \\
\hline S1 & $0.015 \pm 0.001^{\mathrm{c}}$ & $0.092 \pm 0.007^{\mathrm{b}}$ & $6.599 \pm 0.142^{b}$ \\
\hline $\mathrm{S} 2$ & $0.021 \pm 0.002^{\mathrm{a}}$ & $0.074 \pm 0.003^{\mathrm{c}}$ & $5.681 \pm 0.431^{\mathrm{c}}$ \\
\hline $\mathrm{Cp} 1$ & $0.018 \pm 0.002^{\mathrm{b}}$ & $0.068 \pm 0.004^{\mathrm{c}}$ & $5.493 \pm 0.311^{\mathrm{c}}$ \\
\hline $\mathrm{Cp} 2$ & $0.011 \pm 0.001^{\mathrm{d}}$ & $0.084 \pm 0.005^{\mathrm{b}}$ & $10.24 \pm 0.123^{\mathrm{a}}$ \\
\hline $\mathrm{K} 1$ & $0.020 \pm 0.001^{\mathrm{a}}$ & $0.053 \pm 0.005^{\mathrm{d}}$ & $5.454 \pm 0.245^{\mathrm{c}}$ \\
\hline $\mathrm{K} 2$ & $0.019 \pm 0.002^{\mathrm{ab}}$ & $0.051 \pm 0.005^{\mathrm{d}}$ & $6.460 \pm 0.634^{\mathrm{b}}$ \\
\hline WHO, 2008 & 5 & 1 & $5-43$ \\
\hline
\end{tabular}

Where; LSD- Least Significance Difference; $\mathrm{B}_{1}$ and $\mathrm{B}_{2}$ Bilate; $\mathrm{L}_{1}$ and $\mathrm{L}_{2}$-Lante; $\mathrm{A}_{1}$ and $\mathrm{A}_{2}-$ Alge; $\mathrm{S}_{1}$ and $\mathrm{S}_{2}$ - Sile; $\mathrm{CP}_{1}$ and $\mathrm{CP}_{2}$ - Chamo Park; $\mathrm{K}_{1}$ and $\mathrm{K}_{2}-$ Kulfo from Abaya and Chamo Lakes, respectively. Values are mean \pm SD of three sites from both lakes is analyzed individually in triplicate. Mean values in the same column followed by the same superscript letters are not significantly different $(p<$ $0.05)$.

The concentrations of each heavy metal in both lakes were within the same range as background values for reports in literature [17]. The concentration $(\mathrm{mg} / \mathrm{L})$ of zinc in the area of investigation for lake water varies from $0.011 \pm 0.001$ to $0.021 \pm 0.002 ; 0.011 \pm 0.001$ to $0.024 \pm 0.001 \mathrm{mg} / \mathrm{L}$ from Chamo and Abaya lakes. The results show that there was no significant difference in the concentration of zinc between Sile and Kulfo site, Chamo Park and Kulfo site, but there is the significance difference between Sile and Chamo Park at $(\mathrm{P}<0.05)$. As shown in Table 3 , there was no significant difference in the concentration of zinc between Alge $_{1}$ and Alge $_{2}$, Lante ${ }_{1}$ and Bilate 2 sites. The concentration of zinc in Lake Abaya was slightly higher than zinc concentration from Lake Chamo. This is may be due to the agricultural activity around the Lake Abaya was more dominated than Lake Chamo.

The level of cupper concentration in Abaya Lake was ranged from $0.023 \pm 0.002 \mathrm{mg} / \mathrm{L}$ to $0.033 \pm 0.003 ; 0.051 \pm 0.005$ to $0.092 \pm 0.007 \mathrm{mg} / \mathrm{L}$ at Alge $_{2}$ to the Alge ${ }_{1}$, Kulfo and Chamo Park Lake Chamo respectively. The copper concentration from Chamo Lake was higher than the concentration of copper from Abaya Lake. This is may be due to, the Lake Chamo was used for tourism and fishery, the waste from car wash and other disposal was higher than the Abaya Lake. The distributions of Fe concentration in Abaya Lake were ranged from $4.755 \pm 0.350 \mathrm{mg} / \mathrm{L}$ to $7.094 \pm 0.355 \mathrm{mg} / \mathrm{L}$ at Alge and Lante, respectively. While the concentrations of Fe from Chamo Lake were ranged from $5.454 \pm 0.245$ to $10.24 \pm 0.123$ $\mathrm{mg} / \mathrm{L}$ at Kulfo and Chamo Park sites. The result shows that the mean values of the iron concentration between the sampling site from Chamo and Abaya Lakes were not significantly different $(\mathrm{p}<0.05)$. The area in the past has been affected by global climatic change with a shift to a decrease in precipitation peaks and with consequent impact on the lakes. In previous times, those lakes are known by its fish potential as a freshwater lake, contained freshwater fish 
species, and now its fish potential is decreasing time to time and at the same time studies showed the water salinity increased progressively from past to present [7]. Generally, the distribution patterns of all selected metals in both lakes were below the permissible guidelines due to these it has no effect on the aquatic environment and human being who used these lakes $[17,18,21,22]$.

\subsection{Levels of Selected Metals in Tilapia and Barbus Fish}

First of all an understanding of the mechanisms or modes of action for the chemical concern is important such that the appropriate fish organs are selected and sampled. Selection of the appropriate fish organs can be specific to contaminants [23]. In the fish body, the metal is transported through the blood stream and either stored, transformed or eliminated in the liver, kidney or the gills [22]. The levels of selected metal concentrations recorded in the gills, kidney and livers of the two investigated fish species from the two lakes are shown in Tables 4 and 5 . The mean \pm standard deviation, coefficient of variation and least significance difference of Selected metal concentration in Tilapia and Barbus fish observed from ANOVA result at $(\mathrm{p}<0.05)$.

\subsubsection{Levels of Selected Metals in Tilapia and Barbus Fish from Chamo Lake}

The distribution and accumulation of metals in fish organs depends on the metal type, interaction with natural factors, ability to bind metals in forms that are not biologically available, character of mechanisms determining bioaccumulation of metals, and also on the type of tissue, fish species, size and age [23]. In the present study the levels zinc, copper and iron in tissues of gill, kidney and liver parts of Tilapia and Barbus fish sample collected from Abaya and Chamo Lakes were investigated.

Table 4. The selected metal concentrations (mean $\pm S D \mathrm{mg} / \mathrm{kg}$ ) in Barbus and Tilapia fish from Chamo lakes $(n=3)$

\begin{tabular}{|c|c|c|c|c|}
\hline Fish species & Tissue & $\mathbf{Z n}$ & $\mathbf{C u}$ & $\mathbf{F e}$ \\
\hline \multicolumn{5}{|c|}{ Selected Metals in Barbus from Chamo Lake } \\
\hline \multirow{3}{*}{ Barbus Chamo Lake } & Gill & $0.061 \pm 0.005^{\mathrm{b}}$ & $0.025 \pm 0.002^{\mathrm{b}}$ & $3.583 \pm 0.024^{\mathrm{a}}$ \\
\hline & Kidney & $0.076 \pm 0.001^{\mathrm{a}}$ & $0.028 \pm 0.001^{\mathrm{b}}$ & $2.735 \pm 0.015^{\mathrm{b}}$ \\
\hline & $\operatorname{LSD}(0.05)$ & 0.008 & 0.006 & 0.392 \\
\hline \multicolumn{5}{|c|}{ Selected metals in Tilapia from Chamo Lake } \\
\hline \multirow{5}{*}{ Tilapia Chamo Lake } & Gill & $0.083 \pm 0.003^{\mathrm{a}}$ & $0.031 \pm 0.003^{\mathrm{b}}$ & $2.934 \pm 0.049^{b}$ \\
\hline & Liver & $0.074 \pm 0.005^{\mathrm{c}}$ & $0.029 \pm 0.002^{\mathrm{b}}$ & $0.809 \pm 0.03^{\circ} \mathrm{C}$ \\
\hline & $\operatorname{LSD}(0.05)$ & 0.007 & 0.008 & 0.186 \\
\hline & WHO (1985) & $10-75$ & 3.0 & 100 \\
\hline & FEPA (2003) & 75 & 1.3 & 100 \\
\hline
\end{tabular}

Where; LSD-Least Significant Difference, Values are mean \pm SD of the three tissues of fish from each fish species, analyzed individually in triplicate. Mean values in the same column followed by the same superscript letters are not significantly different $(\mathrm{p}<0.05)$.

\subsubsection{Levels of Selected Metals in Tilapia and Barbus Fish from Abaya Lake}

The distribution of metals in fish organs depends on the metal type, interaction with natural factors, ability to bind metals in forms that are not biologically available, excretion of metals, and also on the type of tissue, fish species, size and age [23]. The levels of mean values in the gills, kidney and livers of the two investigated fish species from the Abaya Lake are shown in Tables 5 below.

Table 5. The mean $\pm S D(m g / K g)$ selected metal concentrations in Barbus and Tilapia fish from Abaya lakes $(n=3)$.

\begin{tabular}{|c|c|c|c|c|}
\hline Fish species & Tissue & Zn & $\mathbf{C u}$ & $\mathbf{F e}$ \\
\hline \multicolumn{5}{|c|}{ Selected Metals in Barbus from Abaya Lake } \\
\hline \multirow{4}{*}{ Barbus Abaya Lake } & Gill & $0.061 \pm 0.005^{\mathrm{b}}$ & $0.025 \pm 0.002^{\mathrm{b}}$ & $3.583 \pm 0.024^{\mathrm{a}}$ \\
\hline & Kidney & $0.076 \pm 0.001^{\mathrm{a}}$ & $0.028 \pm 0.001^{\mathrm{b}}$ & $2.735 \pm 0.015^{\mathrm{b}}$ \\
\hline & Liver & $0.070 \pm 0.002^{\mathrm{a}}$ & $0.044 \pm 0.003^{\mathrm{a}}$ & $2.723 \pm 0.091^{\mathrm{b}}$ \\
\hline & $\operatorname{LSD}(0.05)$ & 0.008 & 0.006 & 0.392 \\
\hline \multicolumn{5}{|c|}{ Selected metals in Tilapia from Abaya Lake } \\
\hline \multirow{5}{*}{ Tilapia Abaya Lake } & Gill & $0.083 \pm 0.003^{\mathrm{a}}$ & $0.031 \pm 0.003^{\mathrm{b}}$ & $2.934 \pm 0.049^{\mathrm{b}}$ \\
\hline & Liver & $0.074 \pm 0.005^{\mathrm{c}}$ & $0.029 \pm 0.002^{\mathrm{b}}$ & $0.809 \pm 0.03^{\circ} \mathrm{C}$ \\
\hline & $\operatorname{LSD}(0.05)$ & 0.007 & 0.008 & 0.186 \\
\hline & WHO (1985) & $10-75$ & 3.0 & 100 \\
\hline & FEPA (2003) & 75 & 1.3 & 100 \\
\hline
\end{tabular}

Where; LSD-Least Significant Difference, Values are mean $\pm \mathrm{SD}$ of the three tissues of fish from each fish species, analyzed individually in triplicate. Mean values in the same column followed by the same superscript letters are not significantly different $(\mathrm{p}<0.05)$.

As indicated in the Table above the metal concentrations in 
the fish species did not vary between the sampling sites and $\mathrm{Zn}, \mathrm{Cu}$ concentrations did not differ between fish species ( $\mathrm{p}$ $<0.05)$. However, Fe concentrations were highly significant $(\mathrm{p}<0.05)$ in tilapia than in barbus when the fish species are compared between Chamo and Abaya Lakes.

\subsection{Bioaccumulation Factor (BAF) from Fish to Water Sample}

The bioaccumulation of each of the three selected metals investigated for the different samples of fish parts were quantified with a bioaccumulation factor (BAF). Bioaccumulation Factor; a major concern for environmental contamination, is the extent to which pollutants concentrate from water into aquatic organisms such as fish. The bioaccumulation factors were calculated by dividing the concentration of a metal in edible fish by the total metal concentration in the water sample based on their location as stated in equation below [24]. Water-to-fish bioaccumulation is one of the key components of human exposure to metals through food chain. The BAF was calculated as follows:

$$
\mathrm{BAF}=\frac{\text { Concentrations of SM in fish sample }\left(\frac{\mathrm{mg}}{\mathrm{Kg}}\right)}{\text { Concentration of SM in water sample }\left(\frac{\mathrm{mg}}{\mathrm{L}}\right)}
$$

Table 6. Bioaccumulation factor calculated from two fish species at Chamo Lakes.

\begin{tabular}{|c|c|c|c|c|}
\hline \multicolumn{5}{|c|}{ selected metals analyzed $(\mathrm{mg} / \mathrm{L})$} \\
\hline Sites & Fish species & $\mathbf{Z n}$ & $\mathbf{C u}$ & $\mathbf{F e}$ \\
\hline \multirow{5}{*}{ Chamo } & Lake & 0.017 & 0.081 & 6.654 \\
\hline & Tilapia & 0.056 & 0.045 & 3.527 \\
\hline & $\mathrm{BAF}$ & 3.294 & 0.556 & 0.53 \\
\hline & Barbus & 0.071 & 0.049 & 2.681 \\
\hline & BAF & 4.176 & 0.605 & 0.403 \\
\hline
\end{tabular}

Table 7. Bioaccumulation factor calculated from two fish species at Abaya Lakes

\begin{tabular}{|c|c|c|c|c|}
\hline \multicolumn{5}{|c|}{ selected metals analyzed $(\mathrm{mg} / \mathrm{L})$} \\
\hline Sites & Fish species & Zn & $\mathrm{Cu}$ & $\mathbf{F e}$ \\
\hline \multirow{5}{*}{ Abaya } & Lake & 0.018 & 0.028 & 5.793 \\
\hline & Tilapia & 0.069 & 0.034 & 2.457 \\
\hline & BAF & 3.833 & 1.214 & 0.424 \\
\hline & Barbus & 0.069 & 0.032 & 1.220 \\
\hline & BAF & 3.833 & 1.143 & 0.211 \\
\hline
\end{tabular}

As indicated in the above trend of bioaccumulation factor for selected metal distribution in fish samples of both lake were arranged in the order of: $\mathrm{Zn}>\mathrm{Fe}>\mathrm{Cu}$ (tilapia from Chamo lake), $\mathrm{Zn}>\mathrm{Cu}>\mathrm{Fe}$ (barbus from Chamo Lake), $\mathrm{Zn}>$ $\mathrm{Cu}>\mathrm{Fe}$ (tilapia from Abaya lake) and $\mathrm{Zn}>\mathrm{Cu}>\mathrm{Fe}$ (barbus from Abaya lake).

The highest value of bioaccumulation factor was found to be 4.176 and 3.833 for $\mathrm{Zn}$ in barbus fish collected from Chamo and Abaya Lakes, respectively, whereas the lowest bioaccumulation was obtained in barbus fish for levels of iron $0.403,0.211$ in Chamo and Abaya Lakes, respectively. This might be due to higher mobility of the selected metals with a natural occurrence in water and the low retention of them in the water than other cations. According to the water to fish bioaccumulation factor (BAF) calculated for tested metals and edible fish consumed by local residents, it can be concluded that $\mathrm{Zn}$ was highly accumulated among the investigated metals. However, the higher concentrations of these selected metals are due to the irrigation, solid waste combustion, leakage of pesticides from farm to lake water and vehicular exhausted [24].

\subsection{Comparison of Selected Metal Concentration from the Current Study with Those Reported on the Literature}

\subsubsection{Water}

The comparison of selected metal concentration of the current study with reported literature is compiled in Table 8 .
It is important to compare the amount of selected metals obtained from the analyses of water samples from Abaya and Chamo Lakes with the amounts sited in the literature from country side and other countries. This comparison helps to indicate the differences in composition and existence of deviation from certain guide lines. The possible explanation of the variations in the concentrations of metals between the above all mentioned lakes and Lake Chamo and Abaya could be due to the different sources of pollution, their exposure time for pollutants $[25,26]$. There are some reports from different countries on the levels of selected metals in water samples. The comparison of the values determined in this study with some other reported values were presented in Table 7. From the table, one can see that the concentrations of the metals analyzed in this study within the range of reported values.

Table 7. Comparison of selected metals in Lake Chamo and Abaya water $(\mathrm{mg} / \mathrm{L})$ with reported Literature.

\begin{tabular}{lllll}
\hline \multicolumn{5}{l}{ selected } \\
Sites & Fish species & $\mathbf{Z n}$ & $\mathbf{C u}$ & Fe \\
\hline \multirow{6}{*}{ Abaya } & Lake & 0.018 & 0.028 & 5.793 \\
& Tilapia & 0.069 & 0.034 & 2.457 \\
& BAF & 3.833 & 1.214 & 0.424 \\
& Barbus & 0.069 & 0.032 & 1.220 \\
& BAF & 3.833 & 1.143 & 0.211 \\
\hline
\end{tabular}

\subsubsection{Fish}

The comparisons of the present study with the previous 
studies of the same lake as well as other lakes compiled in Table 8. The maximum mean accumulation of copper and zinc found in Tilapia species collected from Hawassa lake were $0.019 \mathrm{mg} / \mathrm{L}$ of copper and $0.027 \mathrm{mg} / \mathrm{L}$ of zinc and from Lake Abaya $0.014 \mathrm{mg} / \mathrm{L}$ of $\mathrm{Zn}$ and $0.003 \mathrm{mg} / \mathrm{L}$ of $\mathrm{Cu}$ evaluated by $[26,28]$. The accumulations of $\mathrm{Cu}$ and $\mathrm{Zn}$ in Tilapia fish from Lake Hawassa and Ziway were lower than the FAO/WHO and EU recommended limit. Their accumulations were also lower than the maximum result obtained in present study $(\mathrm{Cu}=0.045 \mathrm{mg} / \mathrm{L}$ and $\mathrm{Zn}=0.05$ $\mathrm{mg} / \mathrm{L})$. The amount of Fe obtained $(2.457-3.527 \mathrm{mg} / \mathrm{L})$ were higher than levels of Fe $0.874 \mathrm{mg} / \mathrm{L}$ and $0.032 \mathrm{mg} / \mathrm{L}$ reported by $[26,28]$.

Table 8. Comparison of selected metal accumulations $(\mathrm{mg} / \mathrm{L})$ in fish sample from Chamo and Abaya Lake with Literature report.

\begin{tabular}{llll}
\hline Selected metals & Concentration $(\mathbf{m g} / \mathbf{K g})$ & Location of Lakes & References \\
\hline \multirow{2n}{*}{} & 0.014 & Abaya & 26 \\
& $0.045-0.083$ & Abaya and Chamo & 28 \\
& 0.027 & Awassa and Ziway & 26 \\
$\mathrm{Cu}$ & 0.003 & Abaya & Present work \\
& $0.025-0.069$ & Abaya and Chamo & 28 \\
& 0.019 & Awassa and Ziway & 26 \\
$\mathrm{Fe}$ & 0.874 & Abaya & Present work \\
& $2.457-3.527$ & Abaya and Chamo & 28 \\
& 0.032 & Awassa and Ziway & 24 \\
\hline
\end{tabular}

As mentioned above, the results obtained in this study were compared and found favorable with the findings of other researchers from other parts of the study area. The results of this study were great difference about the contents of trace elements when compared to previous study [26] This difference in metals content may be due to highly irrigation activities around the lake, sold waste deposited to the lake and anthropological activities near the ecosystem, and the presence of agents which either increases or decreases the metal content. Although distribution of pollutants among the various organs within an organism is not uniform but rather they accumulate in specific target organs. Liver, kidney and gills, are target organs for selected metals accumulation in fish that can lead to pathological changes than the muscle tissues. The low levels of binding proteins in the fish muscle may account for their low concentrations of selected metals [29].

\subsection{Pearson's Correlation Selected Metal in Water and Fish Sample and T-test for Sample Analysis}

Table 9. Correlation between selected Metal in Water and Fish Sample.

\begin{tabular}{|c|c|c|c|c|}
\hline \multirow{2}{*}{ Elements } & \multicolumn{2}{|l|}{ Lake Chamo } & \multicolumn{2}{|l|}{ Lake Abaya } \\
\hline & Tilapia fish & Barbus fish & Tilapia fish & Barbus fish \\
\hline $\mathrm{Zn}$ & -0.61777 & 0.69368 & -0.66170 & 0.80715 \\
\hline $\mathrm{Cu}$ & -0.20280 & -0.35896 & -0.76423 & 0.08654 \\
\hline $\mathrm{Fe}$ & -0.43614 & 0.55341 & -0.89777 & -0.03240 \\
\hline
\end{tabular}

In most of the cases, the results showed that copper, zinc and iron have negative correlation in tilapia and copper in barbus fish obtained from Chamo Lake. Similarly $\mathrm{Zn}, \mathrm{Cu}$ in barbus fish show positive correlations at $(p<0.05)$. The value of Pearson's correlation coefficient, $r$ between +0.7 and +1.0 indicate strong positive correlation, however the mostly weak negative association are having a value of $\mathrm{r}$ between 0.7 and -0.3 as recommended by [30]. These may confirm that the three selected elements investigated in this study have similar sources can be related due to having the same topographical area and anthropogenic emission sources [31].

Table 10. Mean, standard deviation, number of triplicate measurement and experimental t-values of the selected metals in Chamo and Abaya Lakes.

\begin{tabular}{|c|c|c|c|c|c|c|c|}
\hline Metals & Lakes & $\mathbf{n}$ & Mean & SD & t-exp. & t-crit. & Conclusion \\
\hline $\mathrm{Zn}$ & $\begin{array}{l}\mathrm{AL} \\
\mathrm{CL}\end{array}$ & 3 & $\begin{array}{l}0.015 \\
0.015\end{array}$ & $\begin{array}{l}0.0006 \\
0.0001\end{array}$ & 0.0 & 2.78 & $\mathrm{H}_{\mathrm{o}}$ retained \\
\hline $\mathrm{Cu}$ & $\begin{array}{l}\mathrm{AL} \\
\mathrm{CL}\end{array}$ & 3 & $\begin{array}{l}0.023 \\
0.078\end{array}$ & $\begin{array}{l}0.002 \\
0.003\end{array}$ & 26.421 & 2.78 & $\mathrm{H}_{\mathrm{o}}$ rejected \\
\hline $\mathrm{Fe}$ & $\begin{array}{l}\mathrm{AL} \\
\mathrm{CL}\end{array}$ & 3 & $\begin{array}{l}5.578 \\
6.353\end{array}$ & $\begin{array}{l}0.153 \\
0.351\end{array}$ & 3.506 & 2.78 & $\mathrm{H}_{\mathrm{o}}$ rejected \\
\hline
\end{tabular}

Where; $\mathrm{AL}=$ Abaya Lake, $\mathrm{CL}=\mathrm{Chamo}$ Lake, $\mathrm{n}=$ number of replicate measurements, $\mathrm{SD}=$ standard deviation, $\mathrm{t}$-exp. $=$ experimental t- value, $\mathrm{t}$-crit. $=$ critical t-value.

There are 4 degrees of freedom for each selected metal measurement and the critical value at $t_{4}=$ from table is 2.78 $(\mathrm{P}=0.05)$. The calculated $\mathrm{t}-\mathrm{values}$ of $26.421,3.506$, for copper, iron, are greater than the critical t-value, here also the null hypothesis is rejected that there is a significant 
difference $(\mathrm{p}=0.05)$ between the mean concentration with respect to copper, iron, between the two lakes. In a series of experiments on the determination of mean difference between selected elements $(\mathrm{Zn}, \mathrm{Cu}$ and $\mathrm{Fe})$ in Tilapia and Barbus fish samples from Chamo and Abaya Lakes were obtained from the calculation of their mean value and standard deviation. The experimental t-value of $\mathrm{Zn}$ and $\mathrm{Fe}$ were less than the critical t-values, this shows there is no significance difference $(p=0.05)$ between the mean values in gills of both fish species collected from Chamo Lake. Although, the experimental t-value of copper in the kidney was not significantly different $(p=0.05)$ between the values of fish species.

\section{Summary and Conclusions}

The study determines selected metals concentrations in edible part of two fish species (Oreochromis niloticus and Labeobarbus intermedius) as well as with water samples collected from Chamo and Abaya, Ethiopian Rift Valley Lakes. An efficient procedure for the digestion of the gills, kidney and liver of fish has been validated through recovery studies. Using the optimal digestion procedure, similar concentrations of trace metals in fishes (Oreochromis niloticus and Labeobarbus intermedius) from the two lakes were observed. Moreover, results revealed absence of any reliable interspecies differences in the content of trace metals in fish tissue. Furthermore, Oreochromis niloticus and Labeobarbus intermedius tend to accumulate trace metals and thus, they may be considered as useful species for monitoring pollution of lakes by trace metals. The high accumulation of selected metal concentration might be caused by the closeness of the site to the highway and anthropogenic source like irrigation activities around the lake. Even though selected metal concentrations in water were very low or negligible, the levels in tissues of fish species were relatively high. The potential sources of these selected metals may be through the food chain obtained from the sediments and algae in the aquatic system.

The BAF values in this research that are different among the type of metals indicate that there are some species which can limit the amount of metal accumulation. The high level of bioaccumulation factor of $\mathrm{Zn}$ shows that was good bioindicator to monitor pollution in the lake water. The quantities of selected metals in fish gill, kidney and liver measured in this study provide baseline information on concentrations and distribution of metals in the two fish species (Oreochromis Niloticus and Labeobarbus intermedius) from Chamo and Abaya Rift Valley Lakes. The Chamo-Abaya Lakes may not be harmful to consumers because the observed values of metals were below the permissible limits issued by FAO/WHO for human consumption.

Finally, Pearson's correlation at 95\% confidence levels of significance was calculated for finding relationship between elements content in water and fish sample. Significantly positive and negative correlation was observed between different elements in water and fish samples. Similarly the mean differences between the values of samples obtained in this study were evaluated by the student's paired t-test at $95 \%$ confidence level. In this study, Excel Microsoft office software was used to calculate the t-values for testing the significance differences of the selected metal concentrations between both lakes and fish species separately. This study focused on only three fish body parts (gill, kidney and liver). Hence, it is recommended to perform research works on other fish organs that have the ability to accumulate trace elements such as muscle, bone, scales, skin and intestine.

\section{References}

[1] Gebremariam, Z. and Pearce, J. G. 2003. Concentrations of heavy metals and related trace elements in some Ethiopian Rift-Valley Lakes and their in-flows Hydrobiological, 429: 171-178.

[2] Guevara-Riba, A., Sahuquillo, A., Rubio R. and Rauret, G. 2004. Assessment of metal mobility in dredged harbour sediments from Barcelona, Spain. Science of the Total Environment, 321: 241-255.

[3] Mwangi, J. M. 2013. Determination of concentration of selected heavy metals inTilapia Fish, Sediments and Water from Mbagathi and Ruiru AthiRiver Tributaries, Kenya. MSc thesis, Kenyatta University, Kenya.

[4] Burger, J., Gaines, K. F., Shane Boring, C., Stephens, W. L., Snodgrass, J. and Dixon, C. 2002. Metal levels in fish from the Savannah River: potential hazards to fish and other receptors. Environmental Research, 89: 85-97.

[5] Nord, L. G., Adams, C. D., Wixson, B. G., Loftin, K. A. and Huang, Y. 2004. Lead, Zinc, Copper and Cadmium in fish and sediments from the big river creek of Missouri's old lead belt. Environmental Geochemical Health, 26: 37-49.

[6] FAO. 1992. Committee for inland fisheries of Africa. Report of the third session of the working party on pollution and fisheries, Accra, Ghana. FAO Fisheries Report in Rome, 471.

[7] Ababu Teklemariam. 2005. Water quality monitoring in Lake Abaya and Lake Chamo Region: A research based on water resources of the Abaya-Chamo basin-South Ethiopia, PhD. Thesis, Siegen University.

[8] Larissa, D., Mesfin Mengesha and Elias Dadebo. 2011. Assessment of heavy metals in water samples and tissues of edible fish species from Awassa and Koka Rift Valley Lakes, Ethiopia. Journals of Environmental Monitoring Assessment, 2777-2778.

[9] Kiflom Gebremedhin and Tarekegn Berhanu. 2015. Determination of some selected heavy metals in fish and water samples from Hawassa and Ziway Lakes. Science Journal of Analytical Chemistry, 3 (1): 10-16.

[10] David, A. A. and Terry, P. 2008. Limit of blank, limit of detection and limit of quantitation. Clinical Biochemistry Review, 29: 49-52.

[11] Meseret Amde, Negussie Megersa, Abi Taddesse and Tesfa Bedassa. 2013. Determination of the levels of selected metals in seeds, flowers and fruits of medicinal plants used for tapeworm treatment in Ethiopia. Toxicological and Environmental Chemistry, 95 (1): 82-100. 
[12] Harvey, D. 2000. Modern analytical chemistry, First Edition, International. Mc Graw Hill.

[13] Authman M. M. and Abbas, H. H. 2007. Accumulation and distribution of copper and zinc in both water and some vital tissues of two fish species (Tilapia zillii and Mugil cephalus) ofLake Qarun, Fayoum Province, Egypt. Pakistan Journal of Biological Science, 10: 2106-2122.

[14] Alemayehu Teshome. 2008. Environment resources and recent impacts in the Hawassa collapsed caldera, Main Ethiopian Rift. Quaternary International, 189: 152-162.

[15] Elizabeth Kebede, Zinabu Gebremariam and Ahgren, H. 1994. The Ethiopian Rift Valley lakes Chemical Characteristics of a Salinity Alkalinity series. Hydrobiological Kluver Academic Publishers, Belgium, 288: 1-12.

[16] FDRE, MoWR. 2002. Ethiopian Guidelines specification for Drinking water quality. Federal Democratic Republic of Ethiopia, Ministry of Water Resources, Addis Ababa, Ethiopia.

[17] WHO (World Health Organisation). 2008. Guidelines for drinking water quality, $3^{\text {rd }}$ edition. Recommendations. World Health Organisation Press, World Health Organisation, Geneva, Switzerland, 1: 1-459.

[18] FAO, 1985. Water Quality for Agriculture. Irrigation and Drainage Paper No. 29, Rev. 1. Food and Agriculture Organization of the United Nations, Rome.

[19] Machado, L. and Griffith, R. 2005. Quality assurance project plan and sampling analysis and assessment plan for fish tissue surveys for the State of Colorado. Fish Tissue QAPP/SAP. 1-25.

[20] Javed, M. and Saeed, M. A. 2010. Growth and bioaccumulation of Iron in body organs of catla, Labeo rohita and Cirrhina mrigala during chronic exposures. International Journal of Agriculture and Biology, 12: 881-886.

[21] USEPA (United State Environmental Protection Agency). 2011. Drinking water quality, Heavy metals, Maximum admissible limit, 3: 105-121.

[22] WHO, 2004. Copper in drinking water. Background document for the development of who guidelines for drinking water quality, Geneva.

[23] Kebede Nigussie, Bhagwan Singh, Chandravanshi and Taddese Wondimu. 2010. Correlation among trace metals in Tilapia (Oreochromis niloticus), sediment and water samples of lakes Awassa and Ziway, Ethiopia. International Journals of Biological and Chemical Science, 4 (5): 1641-1656.

[24] Mulu Berhe, Abraha Gebrekidan and Yirgalem Weldegebriel. 2012. Health risk assessment of heavy metals bioaccumulation in water, sediment and three fish species (Labeobarbus spp, Clarias gariepinus and Oreochromis niloticus) of Tekeze river dam, Tigray, Northern Ethiopia. Journal of Atmospheric and Earth Environment, 1: 19-29.

[25] APHA (American Public Health Association). 1999. American water works association, Water environment federation. Standard Methods of the Examination of Water and Wastewater, $20^{\text {th }}$ ed. New York: American Public Health Association, APHA, AWWA, and WPCF.

[26] Tariku Bekele, Amare Aregahegn, Tesfaye Hailemariam, Tsegu Lijalem and Alle Madhusudhan. 2015. Determination of the levels of major-essential, minor-essential and toxic metals in Tilapia (Oreochromis niloticus), Nile Perch (Lates niloticus) and Bagrus (Bagrus docmac) of Lake Abaya, Ethiopia. International Journal of Modern Chemistry and Applied Science, 2 (1): 50-56.

[27] Belay Tafa and Eshete Assefa. 2014. Detection of copper and zinc in water of Lake Chamo, Arba Minch Ethiopia. World Journal of Chemical Education, 2 (3): 42-47.

[28] Abayneh Ataro, Taddese Wondimu and Chandravanshi, B. S. 2003. Trace metals in selected fish species from lakes Awassa and Ziway, Ethiopia. Ethiopian Journal of Science, 26 (2): 103-114.

[29] Akoto, O., Bismark Eshun, F., Darko, G. and Adei, E. 2014. Concentrations and health risk assessments of heavy metals in fish from the fosu lagoon. International Journals of Environment Research, 8 (2): 403-410.

[30] Raphael, K. K., Vincent, K. N., Louis, K. D. and Kenneth, A. E. 2012. Correlation between heavy metals in fish and sediment in Sakumo and Kpeshie Lagoons, Ghana. Journal of Environmental Protection, 3: 1070-1077.

[31] Hossam, A. Z., Adnan, M. A. and Hisham, N. W. 2017 Baseline concentration of heavy metals in fish collected from Gaza fishing harbor in the Mediterranean Sea along Gaza coast, Palestine. Turkish Journal of Fisheries and Aquatic Sciences, 17: 101-109.

[32] Kisamo, D. S. 2003. Environmental hazards associated with heavy metals in Lake Victoria Basin East Africa Tanzania. African Newlett on occupational Health, 13: 67-69. 